\title{
Wibracje Mitsuku. Archiwum głosu Mirona Białoszewskiego
}

Agnieszka Karpowicz

TEKSTY DRUGIE 2019, NR 3, S. 79-94

DOI: 10.18318/td.2019.3.5 | ORCID: 0000-0001-9593-2350

Słowo żywe jest energią, [...] jest grą, jest więzią.

Bruno de la Salle

\section{Słowo żywe}

O tym, że twórczość literacka Mirona Białoszewskiego jest przesiąknięta mówionością, wiemy już dobrze, niezależnie od tego, czy bardziej przekonywała nas będzie kategoria żywej mowy, oralności, języka potocznego, dźwiękowości tekstu literackiego czy obecność w nim codziennych gatunków mowy². Bezdyskusyjne wydają

1 B. de la Salle Mowa w obronie sztuki słowa żywego, przeł. M.L. Górska, w: Przyjemności opowiadania, red. M. Litwinowicz-Droździel, IKP UW, Warszawa 2006, s. 13.

2 Zob. np. M. Głowiński Białoszewskiego gatunki codzienne, w: Pisanie Białoszewskiego.Szkice, red. M. Głowiński, Z. Łapiński, Wydawnictwo IBL PAN, Warszawa 1993; G. Grochowski Myślane, pisane, opowiadane. Transy Mirona Białoszewskiego, w: Tekstowe hybrydy. Literackość i jej pogranicza, Wydawnictwo Naukowe UMCS, Toruń 2014; A. Hejmej Tekst (dźwiękowy) Mirona Białoszewskiego, "Przestrzenie Teorii”
Agnieszka Karpowicz - dr hab., prof. UW w Instytucie Kultury Polskiej Uniwersytetu Warszawskiego, literaturoznawczyni i kulturoznawczyni, członkini zespołu Pracowni Studiów Miejskich IKP. 
się zarówno oralizacja - nadawanie cech przekazu ustnego tekstom pisanym - prozy i poezji, nieustanne odnoszenie ich do porządku brzmienia żywej mowy, jak i wskazywane już wielokrotnie wielopoziomowe wyznaczniki tej mówioności: procesualność, kontekstowość, język potoczny, niezależne dialogi, odwołanie do plotki ${ }^{3}$ graficzna kompozycja tekstu ${ }^{4}$ czy spektakularność, wydarzeniowość i momentalność społecznej komunikacji”5 stanowiące podglebie tej twórczości. Pisał o tym sam Białoszewski w tekstach dotyczących własnej poetyki i „dramatyki”: „Dążę do tego, żeby to, co pisane, było zapisaniem mówionego. I żeby pisanie nie zjadło mówienia. To, co jest warte z języka mówionego, to się zapisuje. A to z napisanego - jest potem mówione na głos”; „Słowo uwolniło się od balastu. Niby. Po to, żeby szybciej przekazywać. Mniej do słuchu. Druk pomógł. Żeby nam się wyrobiła pamięć wzrokowa. Czytanie sobie, prędkie. W łóżku. Kameralnie. Sklejanie w operę rozdzielonego słowa i muzyki zrobiło się trzecią rzeczą. Powieść czwartą. Ale powieść, kronika, gadanie prozą zawsze istniało".

Mówił o tym w wywiadach, ale też czynił z refleksji na temat relacji między tym, co mówione, a tym, co pisane, integralną część swoich utworów literackich, podobnie jak z rozmyślań o muzyce i zapisów doświadczeń związanych z jej słuchaniem, często w trakcie pisania właśnie ${ }^{9}$. Efekty praktyk

2005 nr 5; A. Karpowicz Powiedziane - zasłyszane - zapisane. Przepisywanie „z życia” w literaturze polskiej lat 70. XX wieku, "Zagadnienia Rodzajów Literackich" 2014 z. 2; tejże Audiosfera, w: Proza życia. Mowa, pismo, literatura: Białoszewski, Stachura, Nowakowski, Anderman, Schubert, Redliński, Wydawnictwa UW, Warszawa 2012; K. Rutkowski Przeciw (w) literaturze. Esej o „poezji czynnej" Mirona Białoszewskiego i Edwarda Stachury, Pomorze, Bydgoszcz 1987; A. Wiedemann Pożegnanie „żywej mowy". W 20-lecie śmierci Mirona Białoszewskiego (1922-1983): o poecie i jego literackich spadkobiercach, "Tygodnik Powszechny" $2003 \mathrm{nr} 25$.

3 Zob. A. Pantuchowicz Białoszewskiego babyz bloku, w: Plotka. Wybór materiałów z VI Konferencji Pracowników Naukowych i Studentów Instytutu Nauk o Literaturze Polskiej Uniwersytetu Śląskiego, red. K. Uniłowski, C.K. Kędera, Górnośląska Macierz Kultury, Katowice 1994.

4 Zob. W. Sadowski Tekst graficzny Białoszewskiego, Wydział Polonistyki UW, Warszawa 1999.

5 K. Rutkowski Białoszewski i proksemika. Proksemika i obcowanie językowe, w: Przeciw (w) literaturze...

6 I. Libucha „Dramatyka"Mirona Białoszewskiego, "Dialog” 1983 z. 10.

7 M. Białoszewski Mówienie o pisaniu, w: Proza stojqca, proza lecąca. Teksty rozproszone i niepublikowane, PIW, Warszawa 2015, s. 385.

8 Zob. M. Białoszewski O tym Mickiewiczu jak go mówię, tamże, s. 355.

9 Zob. A. Poprawa Motywy muzyczne w pisarstwie Mirona Białoszewskiego, "Teksty Drugie” 2004 nr 3; J. Wiśniewski Miron Białoszewski i muzyka, Wydawnictwo UŁ, Łódź 2004. 
magnetofonowych Białoszewskiego, zarchiwizowane na taśmach przez Jadwigę Stańczakową i przechowywane dziś w warszawskim Muzeum Literatury, będące też podstawą wydania serii płyt przez Bôłt Record, zdawałyby się jedynie potwierdzać te rozpoznania. Magnetofon jest potrzebny, ponieważ literaturę trzeba „robić z czegoś żywszego i innego [niż ona sama - A.K.], właśnie z życia”"10 , bliżej niego jest zaś słowo mówione, właściwe codziennym praktykom wypowiedzeniowym.

\section{Energia i wibracja}

Słuchanie nagrań Białoszewskiego - a zwłaszcza Chamowa czy Tajnego dziennika, którym autor nie zdążył i nie chciał sam nadać formy tekstu literackiego i które ukazały się dopiero pośmiertnie, właśnie dzięki istnieniu taśm - tę pewność co do funkcji oralności rozchwiewa. Słychać wyraźnie, że Białoszewski, nagrywając, nie mówi, nie jest spontanicznym improwizatorem, a często nie odgrywa nawet roli aktora-deklamatora. Co zatem robi? Otóż, czyta zapisany tekst, rejestrując ten akt na taśmach. Wykonanie stanowi realizację głosową fragmentu uprzednio przygotowanego na piśmie. Dodatkowo na początku nagrania Jadwiga Stańczakowa lub sam Białoszewski podaje numer taśmy i ścieżki, poeta zapowiada czytany utwór jego tytułem, informuje, że jest on częścią jakiegoś większego cyklu - wszystko to odbywa się więc w zgodzie z logiką piśmienną, choć samo wykonywanie ma charakter mówiony. Oczywiście, wiemy, że to Stańczakowa porządkowała kasety, a samo archiwum jest jej pomysłem ${ }^{11}$. Wiemy też, że praktyka wspomagała po prostu podawanie utworów do druku - Białoszewski nie pisał na maszynie, a jego przyjaciółka-sekretarka była niewidoma, dyktował jej więc tekst, łącznie ze znakami przestankowymi, jak wspominała Stańczakowa, i go nagrywał.

Jednak on sam podczas czytań korzystał z utrwalonego, oryginalnego zapisu, co nie jest możliwe w przypadku ekspresji źródłowo oralnej, właściwej sytuacjom, w których istnieją tylko różne wersje opowieści, nie ma zaś statycznej, jednej podstawy ${ }^{12}$. Między innymi z tego powodu w kulturze typograficznej kojarzy się ją powszechnie, choć niesłusznie, ze spontanicznością,

10 M. Białoszewski Mówienie o pisaniu..., s. 10.

11 Na temat sposobu i historii powstawania nagrań zob. np. J. Kopciński Człowiek transu: magnetofonowe sesje Mirona Białoszewskiego, "Teksty Drugie” $2011 \mathrm{nr}$ 4; T. Sobolewski Jadwiga, Miron, Hoża , Zeszyty Literackie" 2009 nr 2; J. Stańczakowa Dziennik we dwoje, Warstwy, Wrocław 2015. 
dialogiem, oddolnością czy familiarnością ${ }^{13}$. Głos Białoszewskiego tych cech nie ma, pisarz nie posługuje się pamięcią, partie dotyczące wspomnień z odległej lub bliższej przeszłości są również wcześniej zapisane, korzysta on z wszystkich możliwości pisma, w tym taśmy magnetofonowej, która niewątpliwie wiąże się z logiką zapisu i rejestracji, unieruchamiania żywego słowa $^{14}$. Jednocześnie pisarz deklaruje, spierając się z Jadwigą, że pisanie nie jest misterium, ponieważ: „misterium to obrządek. Coś widać. A przy pisaniu nic nie widać. Stawiam znaczki, a mogę i bez, z pamięci"15. Czytając swoje poezje i wiersze, z tej możliwości jednak rezygnuje. Ostatecznie z wymiany zdań ze Stańczakową wynika, że samo pisanie stanowi układanie misterium, które potem ma być „odprawione” na głos.

Słuchając tego magnetofonowego „odprawiania”, wiemy, że Białoszewski nie mówi z pamięci, „z głowy”, że nie improwizuje, nie przyznaje więc prymatu formie mówionej czy ustności w jednoznaczny sposób. Białoszewski po prostu c zy ta, uznając że sam zapis jest w jakiś sposób niewystarczający, niesamodzielny, ale jednak stanowi podstawę seansów głosowych, partyturę misterium. Zapis zawsze poprzedza czytanie, realizację głosową, co sugeruje, że mowa i wykonanie również nie stanowią tu formy docelowej. Tę charakterystyczną, oralno-piśmienną metodę twórczą, potwierdza jedna z notatek Jadwigi Stańczakowej na temat seansu magnetofonowego u przyjaciół na Żoliborzu:

Dalsze nagrywanie. I nagle zdumienie. Robi się jak we śnie. Miron czyta o moim zwiedzaniu Lizbońskiej.

- Potem pojechaliśmy nagrywać na Żoliborz - kończy. - Już.

Naciskam klawisz - stop.

- Miron, jakim cudem? - wykrzykuję.

A Roman:

- Ja też myślałem, że to innego dnia.

- Dziś. Wszystko dziś - śmieje się Miron.

- To on pisał, kiedy pan przewijał taśmę - domyślam się. - Coś tam mruczał „chwileczkę, chwileczkę”. A ja myślałam, że poprawia. ${ }^{16}$

13 W.J. Ong, Oralność i piśmienność. Słowo poddane technologii, przeł. J. Japola, Wydawnictwa UW, Warszawa 2011; M. de Certeau Wynaleźć codzienność. Sztuki działania, przeł. K. Thiel-Jańczuk, Wydawnictwo UJ, Kraków 2008, s. 145.

14 Zob. J. Goody Antropolog i magnetofon, w: Mit, rytuati oralność...

15 M. Białoszewski Chamowo, PIW, Warszawa 2008, s. 149.

16 J. Stańczakowa Dziennik we dwoje..., s. 64. 
8 sierpnia Stańczakowa opisuje wizytę poety, który przyszedł nagrywać prozę i wiersze z 6, 7 i 8 sierpnia: „Jest w uniesieniu i taki rozpisany, że na pewno będzie coś dopisywał. Ja gadam, a on przy stoliku. O, już pisze! Zrobiłam odkrycie, że można to usłyszeć - takie szuranie długopisu"1" .,Pisałem teraz na mojej ławce przed domem, bo ciepło"18 - mówi, przychodząc na sesję magnetofonową do niewidomej przyjaciółki, wpada rano, zastając Jadwigę w piżamie, żeby na gorąco nagrywać, "te nocne" ${ }^{\text {"19 }}$. Wyjazdy z magnetofonem na nagrywania poprzedzają wizyty w mieszkaniu przy Lizbońskiej lub na placu Dąbrowskiego, ponieważ Białoszewski musi zabrać ze sobą bruliony z tekstami:

Więc wybieramy się z Mironem do Ady i Romana. Zabieram magnet, swoje Mitsuku. [...] Najpierw na plac Dąbrowskiego po bruliony. [...] Na Żoliborzu stężony zapach czeremchy, przed domem i w sieni Romanów. [...] Ustawiamy dwa magnetofony - mój i Romana. Roman nawija taśmę i robi próby. Najpierw trochę kosmiczny przyspieszony bełkot. Potem zwyczajny głos Mirona. ${ }^{20}$

Czyta więc na gorąco, świeżo napisane teksty, a cała spontaniczność zawiera się z jednej strony w akcie pisania, a z drugiej, w sytuacji nagrywania, nigdy zaś w samym wytwarzaniu treści, którą rządzą wcześniejsze „bruliony”, zapis, modyfikowany jeszcze przed włączeniem magnetofonu, a zbędny już po nagraniu:

- Zapisz - proszę - zapisz, to takie świetne!

I Miron pisze.

- Może nagramy? - pytam.

- Dobrze. Kończy mi się brulion, to nie będę go zabierać. ${ }^{21}$

Nie sposób oprzeć się wrażeniu, że Białoszewski w piśmie jest oralny, lecz w praktyce oralnej pozostaje piśmienny i że właśnie o tę wymianę i nieustanną, podwójną, homeostatyczną translację, w tej praktyce chodzi.

\footnotetext{
17 Tamże, s. 77.

18 Tamże, s. 47

19 Tamże, s. 43.

20 Tamże, s. 31-32.

21 Tamże, s. 77.
} 
Według Jacka Goody'ego cechą kultury wysoko upiśmiennionej jest przypisywanie „autentyczności” wypowiedziom oratora czy opowiadacza, który nie czyta, lecz mówi, ewentualnie posiłkując się skąpo notatkami. Literatura staje się więc bardziej autentyczna nie tylko za sprawą - charakterystycznych dla pisarstwa Białoszewskiego - autobiografizmu i estetyki prywatności, lecz także dzięki oralizacji, o którym to zjawisku literackim, dość powszechnym w latach 70. XX wieku w polskiej literaturze, pisał Jerzy Bartmiński:

W skali życia publicznego wzrost roli komunikacji ustnej jest - jak się zdaje - [...] rezultatem kryzysu zaufania do przekazu dokonującego się za pośrednictwem druku, jako że jest to środek umykający kontroli odbiorcy, podatny na ukryte manipulacje instytucji pośredniczących sterujących procesami przekazu informacji, często nadużywany, zatem w odczuciu społecznym - mniej wiarygodny; z drugiej zaś strony nawrót do form mówionych wynika z narastającego przekonania o nie dających się niczym zastąpić humanistycznych wartościach komunikacji ustnej, jej naturalności, jej głębokim związku z osobowością człowieka. Mówienie bardziej niż pisanie jest autentycznym świadectwem postawy, wrażliwości, mentalności. ${ }^{22}$

Rejestracje magnetofonowe nie wydają się jednak spontaniczne, są mniej lub bardziej sztuczne, w zależności od sytuacji i charakteru nagrania, w tym sensie, w jakim każda sytuacja głośnego czytania uprzednio przygotowanego tekstu przywodzi na myśl coś nienaturalnego, niespontanicznego, nawet w przypadku aktorskiej sztuki deklamowania, w której wymaga się od wykonawcy pamięciowego opanowania partytury. Pisany scenariusz, partytura w sensie ścisłym, służąca realizacji i wykonaniu na żywo, nie jest potrzebna po nagraniu, ale bez niej nie mogło by się ono odbyć. Ponadto, jak wiadomo, nagranie może być traktowane jako forma docelowa przez niewidomą Jadwigę, chociaż i ona ma świadomość, że przepisując tekst na maszynie, uczestniczy w nieustającym procesie remediacji, ponieważ utwory mają ostatecznie trafić do druku. Białoszewski, nagrywając i wypróbowując ustnie tekst pisany (a potem drukowany), postępuje więc trochę jak hrabina „co prawdziwe szmaragdy podbijała zieloną bibułką"23, by wydawały się prawdziwsze.

22

23

J. Bartmiński Opozycja ustności i literackości, „Literatura Ludowa” 1989 nr 1, s. 3.

M. Białoszewski Rwanie piękności, taśma M. 01434, minuta 31:20-33:14, Muzeum Literatury w Warszawie. Motyw hrabiny pojawia się również z książce Szumy, zlepy, ciągi, a to krążenie 
Wcześniej, przed ustabilizowaniem się praktyki magnetofonowej, w drugiej połowie lat 70., Białoszewski i Stańczakowa nagrywali również nowe fragmenty tekstów na zapisanych już taśmach, co dodatkowo dowodzi, że magnetofonowych rejestracji nie można tu traktować jako formy docelowej. Dlatego przecież zachowały się jedynie fragmenty Pamiętnika z powstania warszawskiego:

Poeta przez lata opowiadał przyjaciołom swoje przeżycia, ale ich nie publikował. Nie tylko z powodu klimatu politycznego, który nie sprzyjał wspomnieniom o powstaniu, także z powodu niepewności co do ich formy. Białoszewski chciał w nich ocalić dynamikę wypowiedzi ustnej, rozwijanej tu i teraz, w obecności słuchaczy, przez opowiadacza, który nie jest funkcją konwencji literackich, ale żywym człowiekiem, identyfikowanym jako osoba dająca świadectwo i podmiot zapamiętanych zdarzeń. $^{24}$

Białoszewski przyjmuje więc rolę mediatora między oralnością a piśmiennością: druk „archiwizuje" mowę, a czytanie na głos staje się „archiwum” rękopiśmiennego zapisu, jak bardzo paradoksalnie by to brzmiało. Literatura przestaje być nieruchoma, a mowa zostaje unieruchomiona. Istotą tego, co zapisane, staje się - właściwa przecież słowu mówionemu - ulotność i efemeryczność; nagrane czytanie czyni przekaz oralny statycznym i dystansuje nadawcę od odbiorcy, „mumifikując” głos niczym pismo ${ }^{25} \mathrm{i}$ uzasadniając jednocześnie zastosowaną tu przeze mnie metaforę archiwum. Rejestracja magnetofonowa, jak każda inna, pełni wobec mowy podobną funkcję, jak aparat fotograficzny dla oka: wzmacnia dystans i obcość między osobą słuchującą i wysłuchiwaną (w przypadku obiektywu aparatu: obserwującą i obserwowana), utrwala to, co ulotne, a utrwalanie i chwytanie zjawisk zmysłowych: słuchowych, wzrokowych, dotykowych, i migotliwych mikrozdarzeń, należy przecież do stałego repertuaru w twórczości autora Chamowa.

Chodzi tu więc również o wymianę i zachowanie równowagi między pozornie opozycyjnymi mediami, o rozwibrowanie każdego z nich, oba stają się zaś nieczyste, mieszane, heterogeniczne i przejściowe, m.in. za sprawą

\footnotetext{
i powtarzanie się wątków, sformułowań i motywów doskonale odpowiada zarówno charakterystyce przekazów oralnych, jak i twórczości Białoszewskiego.

24 J. Kopciński Człowiek transu..., s. 211.

25

Zob. W.J. Ong Oralność i piśmienność...
} 
nasycenia mowy piśmiennością a pisma mówionością. Sytuacja medialna, zjaką mamy tu do czynienia, to kolejny w twórczości Białoszewskiego „zlep”26, taki jak mówienioczytanie czy mówieniośpiewanie, dające się ująć jedynie w płynnej, nieostrej i nieprecyzyjnej kategorii „lektooralności”27, nieustannego zapośredniczania jednego medium przez inne, mediowania między różnymi porządkami percepcji i doświadczenia, ich wzajemnego przekładania na siebie. Co znamienne, sytuacja taka jest charakterystyczna dla obiegów przedliterackich, np. kultur przednowożytnych, i obiegów sakralnych, w których utwór stanowi dobro wspólne jakiejś zbiorowości²8. Jak wiemy, te rejestry literatury, związane nieodłącznie z muzyką i liturgią, niezmiennie fascynowały autora Pamiętnika...

Radykalna niestabilność tekstu ${ }^{29}$ Białoszewskiego, wielość wersji i wariantów stają się doskonale widoczne, kiedy zderzymy ze sobą wielość tekstów publikowanych po wielokroć w różnych zbiorach i tomikach, odkryjemy różnice, czasem bardzo drobne, między treścią nagrań i książek, skolacjonujemy kolejne - uzupełniane i poprawiane właśnie dzięki nagraniom wznowienia dzieł Białoszewskiego czy spróbujemy sprawdzić powtarzalność i prawidłowość, z jaką różne fragmenty powtarzają się w Rozkurzu, Chamowie czy Tajnym dzienniku. Reakcje przyjaciół Białoszewskiego mają wpływ na decyzje o publikacji, a także o kształcie i treści utworów: jak widzieliśmy, Stańczakowa namawia czasem poetę, żeby jakieś wydarzenia czy opowieści zapisywał i nagrał.

Literatura ma więc strukturę otwartą na przemieszczenia, ruchomą i ruchliwą. Przypomina to jej pierwotną, źródłową sytuację w momencie, gdy dopiero zaczynała być literaturą w sensie ścisłym: brak stabilności i ruchomość tekstu, określane przez mediewistę, Paula Zumthora, jako mouvance ${ }^{30}$.

26 M. Białoszewski Szumy, zlepy, ciągi, PIW, Warszawa 2014.

27 J. Goody Mit, rytuałi oralność... Zob. także pojęcie skali literackości i ustności: J. Bartmiński Opozycja ustności i literackości, „Literatura Ludowa” 1989 nr 1, s. 3-8.

28 Kategoria lektooralności zob. J. Goody Mit, rytuał i oralność..., s. 227-237. Na temat przedtypograficznych obiegów literackich zob. m.in. P. Zumthor Intertekstualność i ruchomość tekstu, przeł. A. Karpowicz, w: Almanach antropologiczny 4. Twórczość słowna/Literatura, red. G. Godlewski, A. Karpowicz, M. Rakoczy, P. Rodak, Wydawnictwa UW, Warszawa 2014; T. Michałowska Między słowem mówionym a pisanym; Średniowiecze i „Średniowiecze”, w: Mediaevalia i inne, PWN, Warszawa 1998.

29 P. Zumthor Intertekstualność..., s. 253.

30 P. Zumthor Essai du poétique médiévale, Éditions du Seuil, Paris 1972, s. 307. 
Przekaz ten był albo potencjalnie istniejącym w pamięci zbiorowej i licznych kopiach pre-tekstem, uaktualnianym w oralnych, mniej lub bardziej melicznych, performance'ach ${ }^{31}$, mającym wiele różnych wariantów, albo po prostu pojedynczym, rękopiśmiennym zapisem słów funkcjonujących w kulturze macierzystej ze względu na rytuały, obrzędy, obyczaje, warunki i sytuacje egzystencjalne, a nie ze względu na same utwory. Zumthor doprecyzowuje znaczenie tego terminu, określając zjawisko nie tylko jako elementarny brak stabilności przekazu, jego formy i treści, lecz także jako nieustanną wibrację; również tę, w jaką wprawiają drgania głosu poety, jego oddech ${ }^{32}$. Jak wibrowała - i wibruje nadal, dzięki seansom z Mitsuku - literatura Białoszewskiego?

\section{Gra i więź}

Magnetofonowe seanse potwierdzają, że literatura Białoszewskiego to bardziej proces niż tekst, i właśnie ten proces, a nie utwór literacki, trzeba by ujmować jako dzieło sztuki. Jest on w zasadzie archiwum podwójnego performance'u: pisania (mamy wiele dowodów na to, że odbywało się ono właśnie bardzo sytuacyjnie, ale też spontanicznie: na ławce, na przystanku autobusowym, podczas chodzenia po (pod)warszawskich zaroślach lub zaraz po powrocie z nich), ale i nagrywania czytanego tekstu.

Białoszewski wielokrotnie opisuje bardzo teatralne zabiegi, którym towarzyszyło pisanie: wprawianie się w odpowiedni nastrój czy „trans” lub ustawianie „dekoracji", włączanie odpowiedniej muzyki, świec, chodzenie po korytarzu lub mieszkaniu. Czasem pisarz był w nastroju do nagrań, czasem nie, raz wydawał się tak bardzo usposobiony mistycznie, że aż, jak pisze Stań-

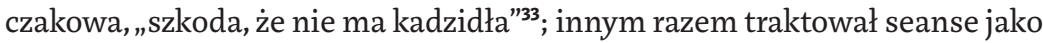
konieczność, co wyraźnie słychać w lekko zmęczonym i niewyraźnym głosie na taśmach Chamowa. Przyjaciółka rozpoznaje wręcz na podstawie sytuacji i nastroju, w jakich odbędzie się nagranie, gatunki magnetofonowego performace'u: „Misterium Sztuki”34 (np. wiersze nagrywane po nocnym pisaniu

31 W tekście odwołuję się do dwóch, bliskich sobie, sposobów rozumienia pojęcia performance, co podkreślam w zapisie. Chodzi tu o sposób istnienia oralnej sztuki słowa. Zob. R. Bauman Sztuka słowa jako performance, przeł. G. Godlewski, w: Literatura ustna, wyb. P. Czapliński, słowo/obraz terytoria, Gdańsk 2010, a także cytowane w tym tekście liczne prace Paula Zumthora. 
i „lataniu po uroczyskach”35), „fachowe”36 w studiu nagrań, podczas których „każde potknięcie wykasowuje się"37, ale i „domowe [...] pełne wdzięku i naturalności"38. One same mają więc swoją gatunkowość zależną od sytuacji, motywacji i sposobu czytania.

O ile wiersze i - specyficzne ${ }^{39}$, ale jednak - deklamacje poetyckie i teatralne znakomicie mieszczą się w nieortodoksyjnie potraktowanej formule poezji dźwiękowej ${ }^{40}$, stanowiącej odmianę poezji konkretnej, to raczej nie odpowiadają wzorcom klasycznie definiowanej poezji oralnej. Jednak czytanie - często monotonne, znudzone i pośpieszne - notatek Chamowa trudno zmieścić w którejkolwiek z tych kategorii: Białoszewskiemu zdarza się wymawiać niestarannie, bez dbałości o dykcję, przerywa, zacina się i poprawia w sposób, który sugeruje zwyczajną pomyłkę w odczytywaniu, nie zaś głosowy eksperyment.

Sztuka Białoszewskiego w okresie późnej prozy to nie ćwiczenie się w doskonałym deklamowaniu po swojemu, to raczej spontaniczne zabieranie magnetofonu do znajomych i organizowanie seansów czytania-nagrywania, to mniej lub bardziej spodziewane wizyty u Jadwigi Stańczakowej i jej Mitsuku, ale też samotne seanse magnetofonowe w mieszkaniu przy ulicy Lizbońskiej. To nabożne włączanie magnetofonu w towarzystwie, przygotowywanie go, sprawdzanie, czy działa: w Dzienniku we dwoje opis każdego nagrywania poprzedza informacja o próbach głosu i działania sprzętu, fazie przygotowawczej. Dla Stańczakowej działania te były wydarzeniem artystycznym, a czytanie stawało się pełnoprawną sztuką, z jej perspektywy docelowym Dziełem

Tamże.

Tamże, s. 75 .

Tamże.

Tamże.

"«Niedawno widziałem i słyszałem w telewizji Mirona Białoszewskiego, który wygdakał fragmenty Norwida, Słowackiego i Wyspiańskiego. Ponieważ Białoszewski łamie cezurę, zaciera rytm i sens wybijając przypadkowe sylaby, tekst był absolutnie niezrozumiały i wszyscy trzej poeci upodobnili się do siebie i do utworów Białoszewskiego»" - napisał Antoni Słonimski po telewizyjnej emisji fragmentów «klasycznego» programu Teatru Osobnego, w którym autor «Obrotów rzeczy» wykonywał fragmenty IV części «Dziadów» Mickiewicza, «Kordiana» Słowackiego i - wspólnie z Ludmiłą Murawską - «Wesela» Wyspiańskiego" (M. Byliniak Wiersze idq do słuchu, http://www.dwutygodnik.com/artykul/3003-wiersze-ida-do-sluchu.html, 18.01.2019).

Tamże. 
nie musiał być wcale tekst. Jej obecność w procesie twórczym pozwala więc zrelatywizować sens praktyki Białoszewskiego. Po części wszystkie te sytuacyjne gatunki performance'u, a także gatunki mówione (od plotki przez opowiadanie po anegdotę), były użytkowe i pełniły funkcję usługową wobec tekstu-literatury. Jednak on sam stawał się również gatunkiem użytkowym, służąc licznym sytuacjom towarzyskim i stanowiąc pełnoprawną sztukę dla jednej z przyjaciółek pisarza.

Sztuka to także obecność słuchaczy, wśród których (a niekoniecznie tylko przed którymi) się występuje, nie czytając tylko dla nich, lecz także „do magnetofonu" zbierającego dźwiękowe ślady performance'u, jednocześnie nie rejestrując dźwięków samej sytuacji towarzyskiej. Zebrani wydają się słuchać w skupieniu, starają się zachować ciszę: „Teraz Miron czyta swoje wiersze z początku października. Potem dalszy ciąg Chamowa. Imieniny Teresy. No nie mogę, muszę chichotać. Takie świetne, a Mirona trzeba było namawiać, żeby to zapisał!”41; „Chichoczę jak głupia. Zasłaniam usta, bo wychodzi na taśmie"42. Na nagraniach czasem słychać właśnie śmiech, nieraz bardzo gromki, jednak szybko się urywający, czasem tłumiony; słychać wyraźne starania o to, żeby na taśmy nie trafiły treści prywatne czy mowa innych uczestników seansu, pogłosy sytuacji, w jakiej nagrywano: dźwięki tramwajów zza okna czy inne szumy zostały zapisane przypadkiem.

Wielbiciel „szumów”, spisujący je z życia, tropiący w przestrzeni miejskiej, w ogóle nie miał więc - jak pozwalają sądzić dostępne materiały - intencji ich nagrywania. „Podsłuchiwacz” rozmów, który lubił „zbyt obfite ploty towarzyskie”43, próbujący „zmieścić” je wraz z kontekstem i oralną sytuacją, a zwykle też brzmieniem, w zdekontekstualizowanym, milczącym tekście literackim, nigdy ich nie zbierał na taśmach, jakby bardziej interesująca była sama wymiana, samo mediowanie i przefiltrowywanie, pośredniczenie między tekstem a życiem tak, aby jego doświadczenie uległo intensyfikacji, którą to moc Richard Bauman przypisuje performance'owi sztuki słowa żywego ${ }^{44}$.

Białoszewski, czytając prozy i poezje utkane z codziennych rozmów, zasłyszanych, ale też prowadzonych przez niego ze znajomymi, nie nagrywa mówiących głosów innych ludzi, lecz zapisuje je, a następnie naśladuje.

41 J.Stańczakowa Dziennik we dwoje..., s. 108.

42 Tamże, s. 48.

Tamże, s. 15.

R. Bauman Sztuka słowa jako performance.... 
Budowanie atmosfery zaskoczenia, zwyczajne próby rozbawienia słuchającego towarzystwa potwierdzają refleksje Pani Stachy, znajomej Stańczakowej. Słuchając na Hożej Portu Praskiego, którego materię stanowią w znacznej mierze rozmowy prowadzone przez Białoszewskiego z Le. podczas spaceru, mówi: „[...] a głos Mirona przyczajony, nie wiadomo, co będzie za chwilę, żart czy serio"45. Czasem są to minikarykatury głosowe sposobu mówienia któregoś ze znajomych, parodie wprawiające Jadwigę w niepowstrzymaną wesołość. Nagrywając swój głos, Białoszewski staje się chętnie medium innych głosów, przywołuje je, przedrzeźnia, parodiuje, wywołuje ${ }^{\mathbf{4 6}}$.

Jacek Kopciński zauważył, że dyktowanie zostało wynalezione po prostu jako technika i początkowo było pozbawione funkcji artystycznej, zyskując stopniowo status rzemieślniczego warsztatu pisarza i jego metody pracy służących sprawdzeniu brzmienia utworu przed jego publikacją, ale też efektu, jaki wywołuje na słuchaczach. Kopciński sytuuje moment, w którym praktyka zaczęła zyskiwać wymiar artystyczny, a jednocześnie nabierać częstotliwości, na około 1975 rok. Wiemy, że był to czas rozstania z Le. i przeprowadzki z miejskiego i ludnego placu Dąbrowskiego na dzikie, puste „stepy” Kępy Gocławskiej. Jadwiga również używa nagrań, aby wywołać i przywołać obecność przyjaciela: są one przesłuchiwane po czasie, nie tylko wtedy, gdy Stańczakowa szuka wolnego miejsca na nowe seanse, lecz także, gdy jest sama w domu albo z Panią Stachą, porządkując taśmy i robiąc ich spis, włącza „Mirona z taśmy" ${ }^{47}$, którego wcześniej sama nagrywała. Głos jest więc nośnikiem obecności i współobecności, jej obietnicą i potwierdzeniem jednocześnie.

Paul Zumthor pisał o sztuce oralnego performance'u jako elementarnej formie teatralności, kładąc nacisk na ciało i nierozerwalność słowa i gestu, a jednocześnie sugerując, że ta podstawowa forma współbycia ma wymiar mikrostruktury społecznej ${ }^{48}$. Można więc spojrzeć na archiwum głosu Białoszewskiego właśnie jako zbiór głosowych śladów i tropów gestów, sytuacji, werbomotorycznych zdarzeń i sytuacji. Jak widzieliśmy, poeta potrafi zapisywać, a potem nagrywać coś, co działo się dosłownie przed momentem, właśnie

45 J. Stańczakowa Dziennik we dwoje..., s. 47.

46 O tym aspekcie nagrań Białoszewskiego, zwłaszcza do nagrań opowiadań z tomu Szumy, zlepy, ciągi, utworów dramatycznych i Kabaretu Kici-Koci zob. N. Ambroziak „To tylko rodzaj czasu. Płeć czasu". Białoszewskiego radio z babq, w: Communicare. Almanach antropologiczny 4...

47 Tamże, s. 37.

48 Zob. P. Zumthor Sonorité, oralité, vocalité, w: Oralités - Polyphonix 16, red. R. Chamberland, R. Martel, Inter éditeur et CRILQ, Québec 1992. 
w drodze na seans magnetofonowy. Czytania prozy, zwłaszcza tej, w której Białoszewski opowiada o tym, co zdarzyło się przed chwilą, są związane z gestem przywoływania, naśladowania, czasem małpowania, zaskakiwania, ale też wygłupiania się - ku uciesze Jadwigi lub wszystkich zgromadzonych. Znamienne, że słuchacze są często jednocześnie bohaterami opowiadanych historyjek, czyli czytanych zapisków, i słyszą to, jak Białoszewski interpretuje czy przedrzeźnia ich sposób mówienia lub ich własne wypowiedzi. Poeta mediuje i przefiltrowuje, znów „podbija szmaragd zieloną bibułką”, wprowadza element sztuczności w to, co jest mu dostępne (i mogłoby być dostępne nam dzięki niezawodnemu Mitsuku) w stanie naturalnym, podobnie jak misternie układa przemyślane, emocjonalne kompozycje ze zbieranych kocanek, skrzypów i innych „zielsk”, szukając dla nich właściwej oprawy, światła i miejsca, by lepiej działały, by intensyfikowały doświadczenia właśnie.

Pożyczanie głosów, naśladowanie sposobów mówienia, charakterystycznej frazy, ale i sformułowań wydaje się zaś bardzo bliskie ściśle literackiej poetyce Białoszewskiego. Tu jednak bardziej istotne jest to, że w tej grupie przyjaciół, a zwłaszcza w relacji z Jadwigą Stańczakową, mamy do czynienia z nieustanną osmozą, przenikaniem się sposobów mówienia i wzajemnym ich pożyczaniem sobie. W tomie Miron. Wspomnienia o poecie, podobnie jak w Dzienniku we dwoje - co zaznacza autor wstępu do jego wydania - przyjaciele bardzo często "mówią Mironem", ale przecież również on nieustannie "mówi (i pisze) nimi". Daleko tu do problemu plagiatu zapożyczania i kradzieży własności, rozstrzygania, czyj właściwie jest ten język pełen „znań się” i innych charakterystycznych sformułowań. To język wspólny, wypracowany w praktyce wzajemnego „obcowania językowego” - jeśli rzecz ująć po Bachtinowsku - czy współuczestnictwa. W 1982 roku Stańczakowa i Białoszewski zamierzali przecież stworzyć i nagrać wspólnie opowiadania na dwa głosy z cyklu Ociemniałe opowieśc $c^{49}$. Białoszewski czytał też i nagrywał dziennik Stańczakowej, skądinąd przedrzeźniając go właśnie i parodiując.

Według Zumthora performance oralny zawsze musi mieć wymiar gestyczny, cielesny, charakteryzujący się jednocześnie głęboko społecznym znaczeniem ${ }^{50}$. Współobecność grupy słuchaczy tu i teraz łączy ich ze sobą, a czas

49 J. Kopciński Człowiek transu..., s. 208.

Szczególną uwagę na ten aspekt myśli Zumthora zwraca Hélène Matte Zumthor: lettres \& nuances, „Post-scriptum" 2016 No. 19, http://www.post-scriptum.org/19-06-zumthor-lettres-nuances/ (21.01.2019). Zob. P. Zumthor Performance, réception, lecture, Le Préambule, Montréal 1990. Na temat cielesnego i społecznego wymiaru praktyki językowej, jaką jest przedrzeźnia- 
performance'u staje się czasem wspólnoty, wspólnie przeżywanym „małym czasem" paru osób. Oralizacja tekstu literackiego lub odwołanie się w nim do potocznych, codziennych, mówionych gatunków mowy również można traktować jako „scenę towarzyskości, w której uczestniczy opowiadacz: to mała społeczność dyskutująca i opowiadająca sobie historie"51 i plotki związane z oralnym obiegiem komunikacji i właściwą jej cyrkulacją korpusu utworów i języków należących do wszystkich, bez praw autorskich. „Wspólnota słów” jest przecież pierwszym aktem „ustalania solidarnościowych więzi”52.

W Dzienniku we dwoje seanse nagrywania, zwłaszcza te u Jadwigi, układają się w pewien stały wzór. Ramą tej "sztuki performance” bywa zwykle przyniesienie przez Białoszewskiego kwiatów, w tym drobiazgowo opisanych w Chamowie „zielsk” i kompozycji z chwastów. Bukiety są przedmiotem rozmów, zachwytów, wąchania, podziwiania. Temu rytuałowi towarzyszy też zwykle jedzenie: przed nagrywaniem, w trakcie seansu lub po nim. „Jeszcze pogadujemy. Ja podżeram sernik"53 - zapisuje Jadwiga 9 października 1975 roku. Biesiadowanie towarzyszy też „nagranioczytaniom” odbywającym się w większym gronie: „Huk tramwajów cichnie po dwunastej. Miron czyta dalszy ciąg Inowrocławia (drugą część Zawału). Półtorej godziny. On dzielnie. My bez znużenia. W przerwie popijamy kawę i jemy kanapki"54. Czynności te mocno podkreślają odświętny, ale i towarzyski charakter sztuki, nie bez powodu kojarzący się z sytuacjami imieninowymi, świeckimi świętami i związanymi z nimi rytuałami, gromadzeniem się i spotykaniem się ludzi ze sobą:

Wydaje się, że literatura czy opowiadanie ustne i generalnie sztuki słowa żywego przejawiają się w równym stopniu we wszystkich dziedzinach codziennego życia, jak i w sytuacjach określanych jako artystyczne a przede wszystkim przy okazjach zgromadzeń ludzkich. Narracje, śpiewy i przemowy wieńczące dobre spotkania są symbolem ludzkich relacji.

nie, zob. L. Rosier Singer ou de la répétition des mots à l'imitation des corps, „Itinéraires. Littérature. Textes. Cultures" 2009 nr 1, s. 50 (https://itineraires.revues.org/331, 18.01.2019).

M. Simard-Houle Dédoublement de la voix narrative et construction des figures de l'auteur chez Jean Lorrain, "Discours Social" 2010 vol. XXXIV, http://legremlin.org/index.php/ouvrages/fiction sduchamplitteraire/33-articlepublicationfictionsdedoublement (17.01.2019). nostka, społeczność, kultura, red. naukowa A.K. Paluch, PWN, Warszawa 2000, s. 338. 
Tak jak w przypadku artystycznych form słowa żywego, miejsca i okazje, w których sztuki słowa żywego są nieodzowne, określane są przez funkcje, które je wywołują. ${ }^{55}$

Towarzyskość, dzielenie się, pożyczanie, gra, rozmowa, przychodzenie „w gości” z kwiatami, poczęstunek, biesiada przy kanapkach i serniku wszystkie te sytuacje są naturalnymi siedliskami literatury Białoszewskiego: niezbywalnymi elementami zarówno jego pojedynczych performance’ów,jak i całego dzieła-procesu. I wszystkie je warto potraktować poważnie, nie tyle jako dodatki do literatury czy ciekawostki, środowiskowe plotki i konteksty, ile jako sztukę rozumianą z kolei jako performowanie przyjaźni, sytuacji społecznej, jej wytwarzanie i pielęgnowanie, a przede wszystkim - wspólnoty, wśród której literatura rodzi się gdzieś między kanapką, anegdotą, plotką, sernikiem a podśmiewaniem się ze znajomych, w sercu tego, czym jest towarzyskość i zabawa społeczna ${ }^{56}$, w ramach której sam tekst staje się czymś wspólnym, czym można się dzielić i wymieniać i czymś, co można „wygdakać” albo „mówić sobie” bez patosu. Taka sztuka w polskiej kulturze wciąż pozostaje albo niepoważnym i nieważkim przedmiotem kpin, albo modelem alternatywnego projektu twórczego współbycia społecznego, do którego realizacji potrzebny jest jednak zawsze performer z jego mocą „przekształcania struktur społecznych"57.

B. de La Salle Mowa w obronie sztuki...

56 J. Huizinga Homo ludens, przeł. M. Kurecka, W. Wirpsza, Czytelnik, Warszawa 1998.

57 R. Bauman Sztuka słowa jako performance..., s. 230. 


\section{Abstract}

\section{Agnieszka Karpowicz}

UNIVERSITY OF WARSAW

Wibracje Mitsuku: Miron Białoszewski's Voice Archive

The magnetic tape recordings archived at the Museum of Literature in Warsaw, especially the recordings of Miron Białoszewski's voice, present an entire spectrum of the everyday oral genres that constitute Białoszewski's artistic and social performance. The ontological status of his literary texts and his work's cultural and social function are problematised by the fact that these practices play an essential role in the creative process and are related to situational spoken genres, which in turn are embedded in the everyday. Karpowicz also discusses in how far Białoszewski's everyday practices are artistic and what we can say about their genre.

\section{Keywords}

Miron Białoszewski, archive, voice, spoken word, everyday genres, oral storytelling, magnetic tape, performance, Jadwiga Stańczakowa, community, conviviality 